\title{
Assessing the Anthropogenic Impact on Heavy Metal Pollution of Soils and Sediments in Urban Areas of Azerbaijan's Oil Industrial Region
}

\author{
Hadiya Khalilova ${ }^{1 *}$, Vagif Mammadov ${ }^{2}$ \\ ${ }^{1}$ International Ecoenergy Academy, \\ 5 M. Arif st., AZ1073 Baku, Azerbaijan \\ ${ }^{2}$ Institute of Geology and Geophysics of Azerbaijan National Academy of Sciences \\ 119 H. Cavid av., AZ1143 Baku, Azerbaijan
}

Received: 15 September 2015

Accepted: 13 November 2015

\begin{abstract}
This paper presents the result of studies of heavy metal pollution in soils and sediments caused by various anthropogenic sources to assess the environmental impact of human activities in the major industrial region of Azerbaijan, the Absheron peninsula. Soil and sediment samples were analyzed for $\mathrm{As}, \mathrm{Cd}, \mathrm{Hg}$, $\mathrm{Pb}, \mathrm{Cr}, \mathrm{Cu}$, and $\mathrm{Zn}$ using inductively coupled plasma-optical emission spectrometry (ICP-OES) and cold vapor atomic fluorescence (CVAF) methods. The results of analyses showed that the main concentrations of such toxic metals as $\mathrm{Hg}, \mathrm{Cd}$, and $\mathrm{Pb}$ were $0.1,2.40$, and $302 \mathrm{mg} / \mathrm{kg}$ in the soil samples, and $0.028,2.7$, and $29 \mathrm{mg} / \mathrm{kg}$ in the sediment samples, respectively. These values are several times higher than the standards established by the Azerbaijani Cabinet of Ministers for the Absheron soils. The highest concentrations of metals were found in soils from the area of a highway and in the sediments of the largest natural lake of the peninsula, Boyuk, whose shores are subjected predominantly to oil industry's wastewater. The pollution index (PI), enrichment factor $(\mathrm{EF})$, geoaccumulation index $\left(\mathrm{I}_{\text {geo }}\right)$, and ecological risk factor $\left(\mathrm{E}_{i}\right)$ were calculated to assess the level and potential ecological risk of heavy metal pollution. Analysis of the calculated values of PI, EF, $\mathrm{I}_{\mathrm{geo}}$, and $\mathrm{E}_{i}$ indicate the contribution of anthropogenic sources to heavy metal accumulation in the soils and sediments of the study area.
\end{abstract}

Keywords: heavy metals, enrichment factor, geoaccumulation index, soil, sediment

\section{Introduction}

Fast-growing industries and increases in human population cause important environmental problems in many industrial regions worldwide. Pollution of the environment by toxic organic and inorganic substances has become a serious concern because of their negative impact on all ecosystem components, including man. Heavy

*e-mail: khalilova@rambler.ru metals are the most hazardous environmental pollutants due to their toxicity and accumulation ability. There are different sources of heavy metals in the environment. These sources can be both of natural or anthropogenic origin. They occur naturally in rocks and soils, but mainly in forms that are not available to biota, such as constituents in rocks and soil minerals. When the metals are derived from anthropogenic sources, this can strongly influence their speciation and hence bioavailability $[1,2]$. Industrial discharges, vehicular emissions, metal mining, biosolids, atmospheric deposition of particles, and land application 
of fertilizers are anthropogenic sources of heavy metal pollution [3-7].

Heavy metals are mainly gathered in soils and sediments. Heavy metals most commonly found at contaminated sites are lead $(\mathrm{Pb})$, chromium $(\mathrm{Cr})$, mercury $(\mathrm{Hg})$, arsenic (As), zinc $(\mathrm{Zn})$, cadmium $(\mathrm{Cd})$, copper $(\mathrm{Cu})$, and nickel (Ni) [8]. It is well known that heavy metals are not degradable and their total concentration in the ecosystem persists for a long time. Getting in soil, heavy metals could be adsorbed and accumulated in different parts of plants through root systems. It has been observed that the pollution caused by heavy metal does not only result in adverse effects on various parameters relating to plant quality and yield, but also causes changes in the size, composition, and activity of microbial communities $[9,10]$. Concentrated in soils, heavy metals can be washed into lakes, rivers, and bays. Due to their migration and accumulation in the environment, most heavy metals can easily enter the food chain and create serious threats to human health $[8,11$, 12].

Along with other industrialized regions of the world, the Absheron peninsula of Azerbaijan couldn't avoid heavy metal pollution.

The Absheron peninsula is situated on the western coast of the Caspian Sea in the southwestern extremity of the Great Caucasus mountain ridge. It occupies a territory of 200,000 ha. The region is characterized by a dry subtropical climate and strong northern winds. The average annual air temperature is $+14.2^{\circ} \mathrm{C}$, average annual rainfall is about $200-300 \mathrm{~mm}$. The soil type is mainly gray-brown and coastal sandy soils. About $70 \%$ of the republic's industrial potential is concentrated in the Absheron peninsula, including 60\% of onshore oil production. Exploration and development of oil-gas fields has resulted in the pollution of a large territory by crude oil, drill cuttings, and wastewater. Today, pressure on the environment in the peninsula is increasing continuously due to the ever-increasing population, plus industrial and urban growth [12].

Past studies have indicated that there are high concentrations of contaminants in soils and water systems of the Absheron peninsula [12-16]. The degree of oil contamination in soils varies from 20 to $30 \%$ and more. There are more than 200 reservoirs of natural and artificial origins, of which a considerable part is polluted by oil products. Most oils have certain content of metals. Tars and asphaltenes are a heavy fraction of oil constituting trace elements, including metals. Studies have revealed high concentrations of toxic heavy metals in sediments of some coastal lakes subjected to oil industrial wastewater.

In order to find a proper solution to the problem, there is a need to identify the sources of heavy metal pollution in ecosystems while evaluating the contribution of natural and anthropogenic factors and the potential ecological risk posed by individual elements.

Various approaches were used to assess environmental quality. Many calculation methods have been proposed by authors for evaluating heavy metal pollution in soils and sediments. The most widely used methods are calculations of single pollution index ( $\left.\mathrm{PI}_{i}\right)$, enrichment factor (EF), geoaccumulation index (Igeo), Nemerow pollution index $\left(\mathrm{PI}_{\mathrm{N}}\right)$, and potential ecological risk index (RI) [17-20].

In this study, we investigated the heavy metal pollution of soils from two types of land uses in the study site and the sediments of two natural water basins: Boyuk-shore and Bulbula lakes that had undergone long term impact of anthropogenic sources. For the first time, the overall pollution status of the study area was evaluated with a calculation of pollution indices of heavy metals including the single pollution index $\left(\mathrm{PI}_{i}\right)$, geoaccumulation index $\left(\mathrm{I}_{\text {geo }}\right)$, enrichment factor $(\mathrm{EF})$, and ecological risk factor $\left(\mathrm{E}_{i}\right)$.

\section{Materials and Methods}

A total of 42 soil samples were collected from two different areas of the study site: 25 in the vicinity of oil wells and 17 within a $10 \mathrm{~m}$ distance of the Baku-Mardakan highway. The depth of soil sampling was 0-0.2 m. Holes were dug mechanically with a special portable instrument designated for this purpose. Sediment samples were collected from Boyuk-shore and Bulbula lakes. Fifteen samples were taken from the surface layers (at 10-15 cm depth) of the sediments of each lake using a sediment sampler.

Boyuk-shore lake is situated in the center of Absheron peninsula at $12 \mathrm{~m}$ above sea level (Fig. 1). It is the largest and most polluted lake in the peninsula with 45 million $\mathrm{m}^{3}$ volume and $15 \mathrm{~km}^{2}$ surface area, and maximal depth of $4.2 \mathrm{~m}$. Boyuk-Shore is an enclosed water body that receives all underground flows from surrounding territories. Starting in the 1930s, a large amount of oil industrial waters were continuously released to this lake. According to the estimates of the Ministry of Ecology and Natural Resources, total daily input to the lake from 49 industrial and municipal sources amounted to $18,000 \mathrm{~m}^{3}[21,22]$.

Bulbula Lake is situated in the center of the Absheron peninsula at $8 \mathrm{~m}$ below ocean level. It is an enclosed saline basin with $2 \mathrm{~km}^{2}$ surface area. Its maximal depth is 3-4 m. The lake is located near residental areas, and is therefore permanently subject to the impact of domestic waste [22].

The samples were air-dried, cleaned from sand, stones, and plant debris passing through a 2-mm Nylon sieve, and stored in special glass tubes at room temperature. Before analysis each sample $(0.2 \mathrm{~g})$ was powdered finely and digested by acids (1:3 $\left.\mathrm{HF}: \mathrm{HNO}_{3}\right)$ according to the U.S. Environmental Protection Agency method [23]. The digestion liquid was then evaporated to remove HF. The obtained residuum was dissolved in nitric acid $\left(\mathrm{HNO}_{3}\right)$ solution and diluted with distilled water for measuring the concentrations of metals.

The inductively coupled plasma-optical emission spectrometry (ICP-OES) method was used in the analysis of heavy metals ( $\mathrm{As}, \mathrm{Cd}, \mathrm{Cr}, \mathrm{Cu}, \mathrm{Pb}, \mathrm{Zn}$, and $\mathrm{Mn}$ ), except $\mathrm{Hg}$, which was analyzed by the cold vapor atomic fluorescence (CVAF) method. 
In order to assess heavy metal contamination of soils and sediments the following pollution indices were calculated:

\section{Pollution Index (PI)}

The pollution level of each heavy metal was evaluated with pollution index $\left(\mathrm{PI}_{i}\right)$, calculated as the ratio between the metal concentration $\left(\mathrm{C}_{i}\right)$ in sample and its reference value-national criteria of the metal $\left(\mathrm{S}_{i}\right)$ :

$$
\mathrm{PI}_{i}=\frac{C_{i}}{S_{i}}
$$

Maximum permissible concentrations (MPC) of pollutants established by Azerbaijani legislation were taken as $\mathrm{S}_{i}$ values.

\section{Enrichment Factor (EF)}

Enrichment factor (EF) was initially calculated to identify the origin of elements in the atmosphere, precipitation, or seawater, and it was further extended to the study of soils, aquatic sediments, and other components of the ecosystem [24]. In this study, the enrichment factors of heavy metals in soils and sediments are calculated to assess the contribution of anthropogenic sources to the natural levels of heavy metals in the Absheron soils and lake sediments. The following formula was used to calculate EF:

$$
\mathrm{EF}=\frac{C_{i} / C_{r}}{B_{i} / B_{r}}
$$

$\ldots$ where $\mathrm{C}_{i}$ and $\mathrm{C}_{r}$ are the concentrations of the target metal and the reference metal in the sample, while $\mathrm{B}_{i}$ and $\mathrm{B}_{r}$ are the background concentrations $(\mathrm{BC})$ of the target metal and the reference metal for the natural soils of the Absheron peninsula. Immobile elements such as $\mathrm{Al}, \mathrm{Fe}, \mathrm{Ti}$, or Mn have been used as reference metals for $\mathrm{EF}$ calculation [17]. EFs for all the heavy metals were calculated using $\mathrm{Mn}$ as the reference metal in our study because $\mathrm{Mn}$ is relatively immobile for Absheron conditions [25].

\section{Index of Geoaccumulation $\left(\mathrm{I}_{\text {geo }}\right)$}

A geoaccumulation index was originally defined by Muller [24] for the evaluation of metal contamination in aquatic sediments, but it was also applied in assessing the metal contamination of soils. The formula used for the calculation of geoaccumulation index soils and sediments is:

$$
I_{g e o}=\log _{2}\left(\frac{\mathrm{C}_{n}}{1.5 B_{n}}\right)
$$

$\ldots$ where $\mathrm{C}_{n}$ is the measured content of element $(n), \mathrm{B}_{n}$ is the $\mathrm{BC}$ of element $n$, and 1.5 is the background matrix correction factor due to lithogenic effects (the constant 1.5 is introduced to minimize the effects of possible variations in the background values that may be attributed to lithologic variations in soils).

\section{Ecological Risk Factor}

The potential ecological risk of heavy metal pollution in the soils and sediments of water basins in the study area

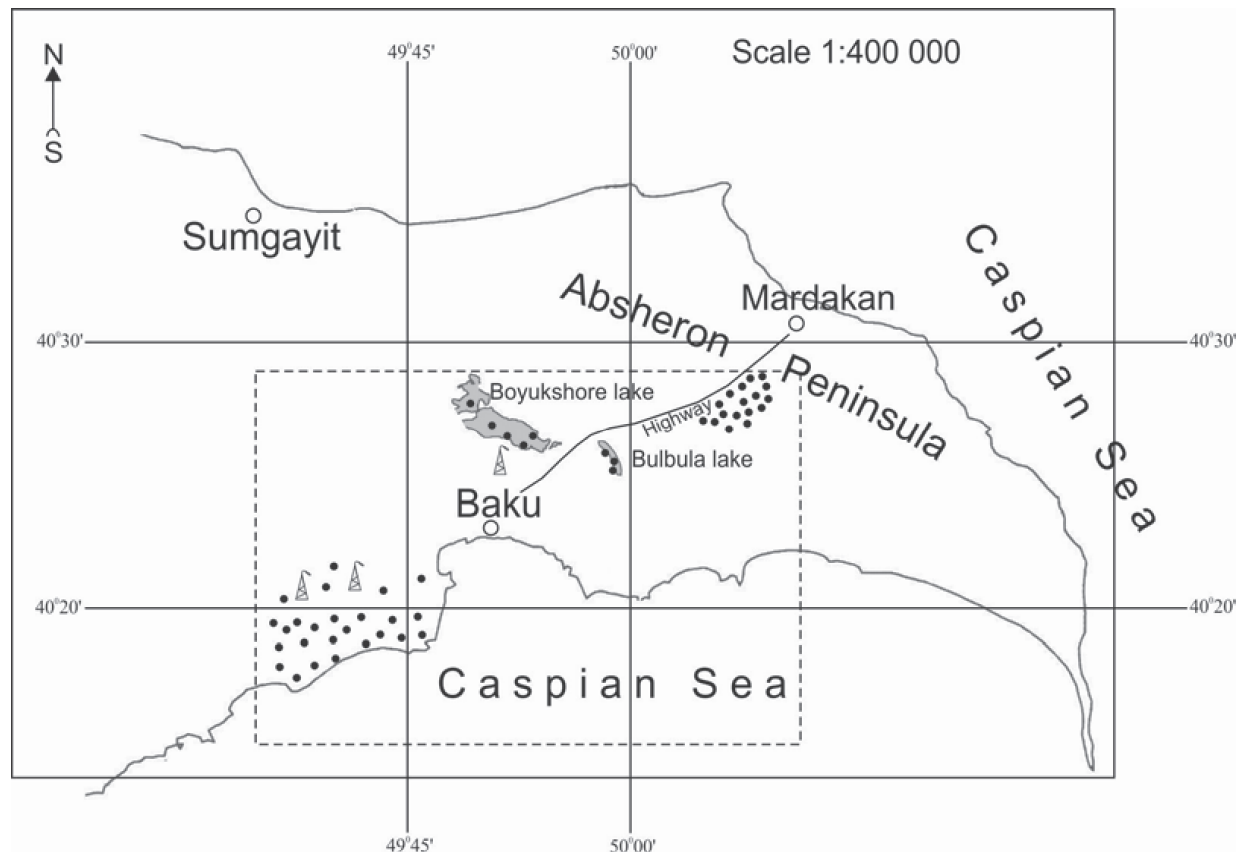

Fig. 1. The study area and sampling site locations in the Absheron Peninsula. 
Table 1. MPC, BC, and toxic-response factors of heavy metals.

\begin{tabular}{|c|c|c|c|c|c|c|c|}
\hline Metals & $\mathrm{Hg}$ & $\mathrm{Cd}$ & $\mathrm{As}$ & $\mathrm{Pb}$ & $\mathrm{Cu}$ & $\mathrm{Cr}$ & $\mathrm{Zn}$ \\
\hline $\begin{array}{c}\mathrm{MPC} \\
(\mathrm{mg} / \mathrm{kg})\end{array}$ & $2.1^{*}$ & 1.0 & 2.0 & 32.0 & 3.0 & 6.0 & 23.0 \\
\hline $\begin{array}{c}\mathrm{BC} \\
(\mathrm{mg} / \mathrm{kg})\end{array}$ & 0.4 & 3.0 & 15 & 20 & 100 & 40 & 70 \\
\hline $\mathrm{T}_{i}$ & 40 & 30 & 10 & 5 & 5 & 2 & 1 \\
\hline
\end{tabular}

*Note: the value of 2.1 is acceptable only for $\mathrm{Hg}$ pollution of soils in non-residential areas.

was assessed using the ecological risk index (RI) [26]. RI is the comprehensive potential ecological index, which is the sum of individual heavy metals $-\mathrm{E}_{i}$. It represents the sensitivity of the biological community to the toxic substance and illustrates the potential ecological risk caused by the overall contamination [20]. The RI was calculated as the sum of risk factors of the heavy metals:

$$
\mathrm{RI}=\sum E_{i}
$$

...where $\mathrm{E}_{i}$ is the single risk factor for heavy metal $i$, and is defined as:

$$
\mathrm{E}_{i}=\mathrm{T}_{i} f_{i}=\mathrm{T}_{i} \frac{C_{i}}{B_{i}}
$$

...where $T_{i}$ is the toxic response factor for heavy metal $i$. The ratio $f_{i}$ the metal pollution factor calculated from the measured concentration $\mathrm{C}_{i}$ and the background concentration $\mathrm{B}_{i}$ of metal in soils. MPC and $\mathrm{BC}$, and the $\mathrm{T} i$ values defined by Hakanson for the measured heavy metals used during the calculation of pollution indices, are given in Table $1[25,26]$.

\section{Results and Discussion}

The results of studies are summarized in Tables 2 and 3.

Table 2 presents the results of laboratory analyses and the mean values of $\mathrm{PI}_{i}, \mathrm{E}_{i}, \mathrm{EF}$, and $\mathrm{I}_{\text {geo }}$ for heavy metals in soils from two sites, including the area of oil fields and at $10 \mathrm{~m}$ distance from a highway in the Absheron industrial region. As can be seen from the table, in samples from the oil field area the concentrations of the majority of heavy metals analyzed were found to be several times higher than their MPC accepted in the republic, indicating that the area is subject to anthropogenic impact. The contents of most toxic metals like $\mathrm{As}, \mathrm{Pb}$, and $\mathrm{Zn}$ ranged from 3.4 to $8.2 \mathrm{mg} / \mathrm{kg}, 14.3$ to $42.2 \mathrm{mg} / \mathrm{kg}$, and 11.5 to $105 \mathrm{mg} / \mathrm{kg}$, respectively. The contents of $\mathrm{Cd}$ and $\mathrm{Hg}$ in these soils were not greater than their permissible levels. Meanwhile, the soils collected from the highway area had high contents of Cd ranging from 1.30 to $5.80 \mathrm{mg} / \mathrm{kg}$ against its MPC of $1.0 \mathrm{mg} / \mathrm{kg}$. Along with $\mathrm{Cd}$, increasingly high levels of $\mathrm{Cr}, \mathrm{Pb}$, and $\mathrm{Zn}$ were found in this site. This is evidence of

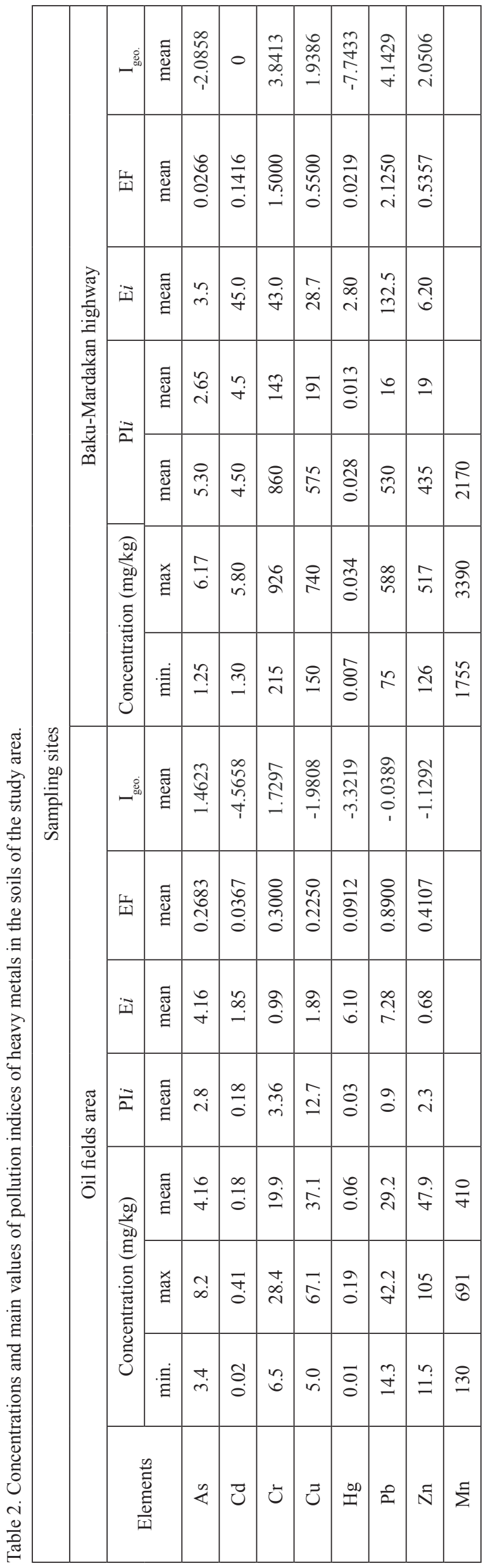




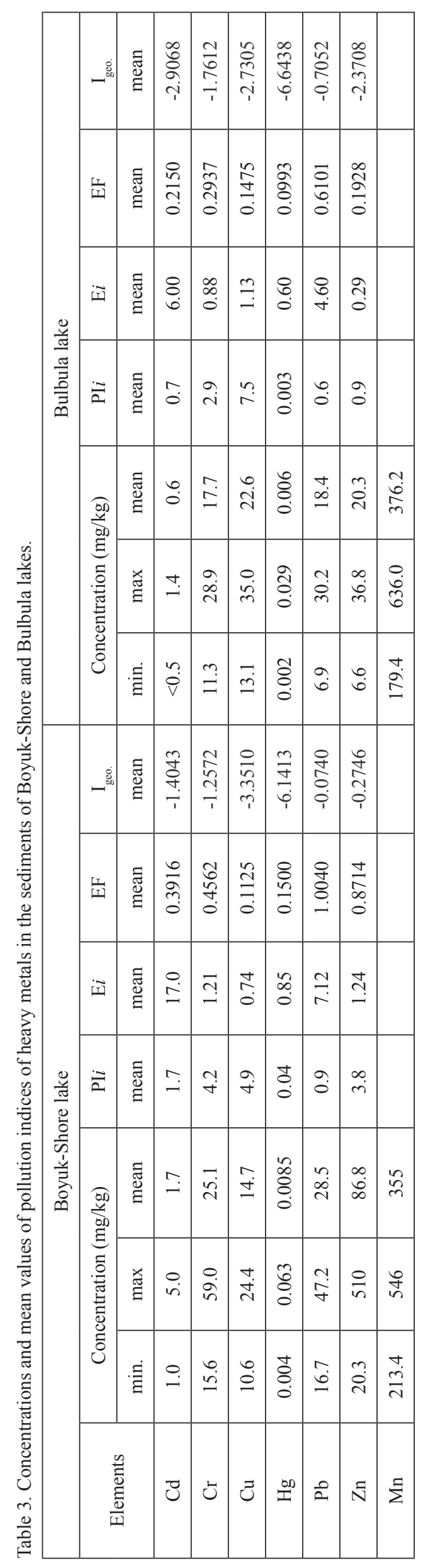

the fact that transport emissions are greatly contributing to heavy metal pollution of ecosystems in the peninsula.

According to their effects on the environment, the studied metals fall within the following categories [13]:

1. $\mathrm{As}, \mathrm{Hg}, \mathrm{Pb}, \mathrm{Cd}$, and $\mathrm{Zn}$ : super dangerous;

2. $\mathrm{Cr}$ and $\mathrm{Cu}$ : dangerous.

The $\mathrm{PI}_{i}, \mathrm{E}_{i}, \mathrm{EF}$, and $\mathrm{I}_{\text {geo }}$ values given in the table are the means of these indices from at least 10 samples.

On the basis of the classification recognized by authors for $\mathrm{I}_{\mathrm{geo}}, \mathrm{E}_{i}$, and $\mathrm{EF}$ [26-28], five categories can be distinguished for evaluating heavy metal pollution levels (Table 4). When comparing the data presented in Table 2 with the pollution classes listed in Table 4, an oil field area can be categorized as unpolluted by $\mathrm{Pb}$, $\mathrm{Cd}, \mathrm{Zn}, \mathrm{Cu}$, and $\mathrm{Hg}$, and moderately to strongly polluted by As and $\mathrm{Cr}$, which mean values of $\mathrm{I}_{\text {geo }}$ are greater than 1 to some extent. The calculated mean values of EF ranges from 0.0367 for $\mathrm{Cd}$ to 0.8900 for $\mathrm{Pb}$, indicating that the site is characterized by the $1^{\text {st }}$ classification level - depletion to mineral enrichment. With the mean $E i$ values for individual metals in the range of $0.68(\mathrm{Zn})$ to $7.28(\mathrm{~Pb})$, the soils of the oil field area have low potential ecological risk with respect to heavy metal pollution. The values of pollution indices for the soils of the site polluted predominantly by transport emissions varied from their values for the oil-polluted site. The soils in this area had the highest pollution indices for $\mathrm{Pb}$. The mean values of $\mathrm{I}_{\text {geo }}, \mathrm{EF}$, and Edi, of $\mathrm{Pb}$ were 4.1429, 2.1250 and 132.5, respectively, representing strongly polluted, moderately enriched, and of considerable ecological risk classes. According to the $\mathrm{I}_{\mathrm{geo}}$ values, the site belongs to a strongly polluted area with respect to $\mathrm{Pb}$ and $\mathrm{Cr}$ and from a moderately to strongly polluted area with respect to $\mathrm{Zn}$ and $\mathrm{Cu}$. $\mathrm{Hg}$ and As had the lowest pollution indices in the soils of this site.

Enrichment factor is an important tool for identification of both pollution levels and sources of heavy metals in soils and sediments.

Fig. 2 shows the minimum, maximum, and mean values of $\mathrm{EF}$ in soil and sediment samples from different locations of the study site. According to the EF values of the studied heavy metals, a major part of the soils from the territory of oil fields is in the state of depletion to mineral enrichment. With the exception of $\mathrm{Pb}$, the evaluated $\mathrm{EF}$ values of heavy metals are less than 1 , which could be associated with the composition of the parent materials of soils [18]. Meanwhile, $\mathrm{Pb}$ showed maximum EF value greater than 2.4, indicating the impact of anthropogenic sources.

The soils collected from the territory of the highway had the highest values of $\mathrm{EF}$ for $\mathrm{Pb}$ and $\mathrm{Cr}$. Based on the maximum and mean $\mathrm{EF}$ values of $\mathrm{Pb}$ and $\mathrm{Cr}$, this territory could be classified as a moderate enrichment area.

Overall, the level of heavy metal enrichment in the soils of the study area decreased in the following order: $\mathrm{Pb}$, $\mathrm{Cr}>\mathrm{Zn}, \mathrm{Cu}>\mathrm{As}, \mathrm{Cd}>\mathrm{Hg}$. Increased levels of $\mathrm{Pb}$ in the soils of the study site are due to the deposition of the atmospheric emissions from transport and various industrial sources, which could be carried over long distances. 

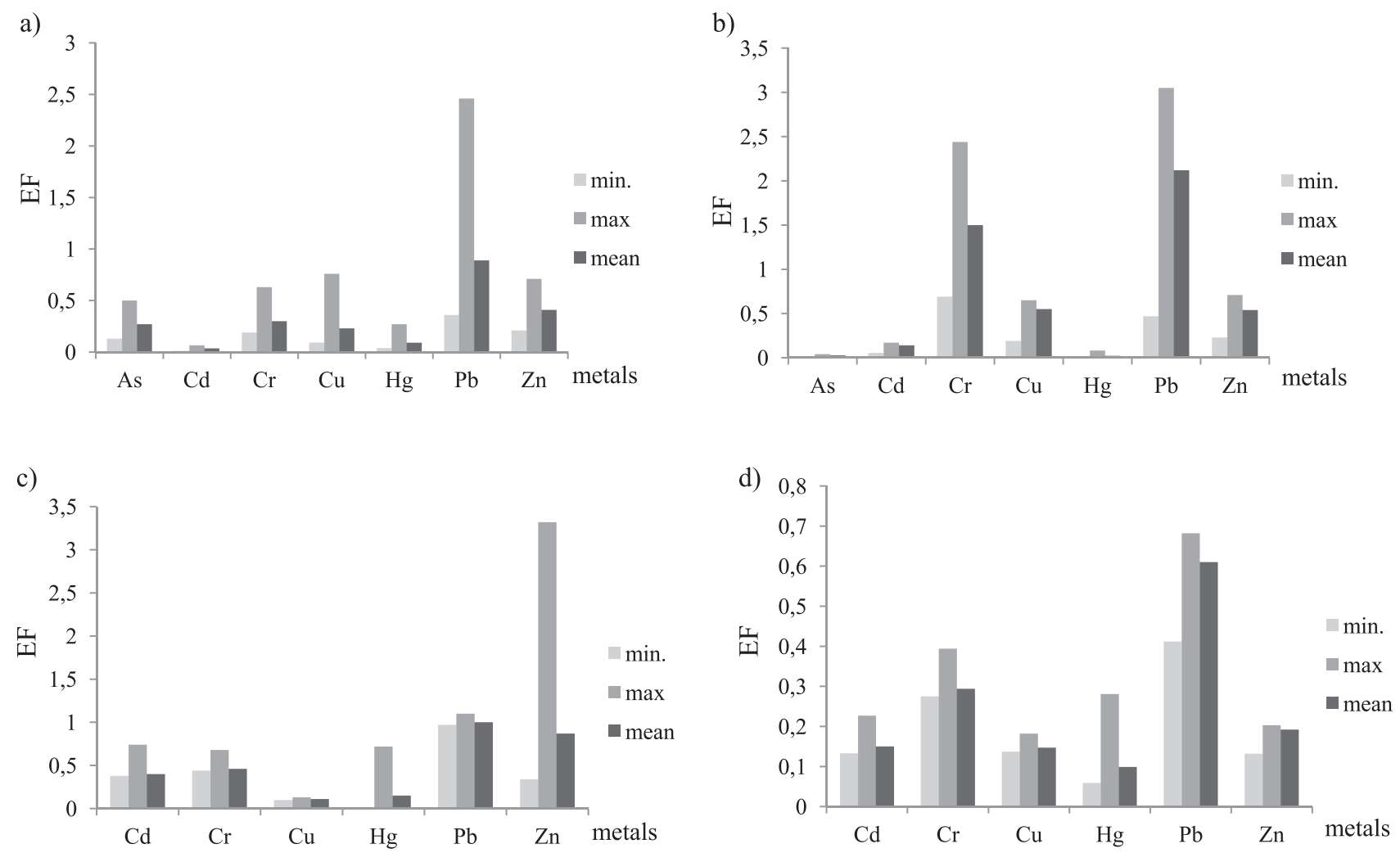

Fig. 2, The average values of EF of heavy metals in soils and sediments ( $\mathrm{n}=10)$ : (a) oil field area, (b) along highway, (c) Boyuk-Shore Lake, and (d) Bulbula Lake.

a)

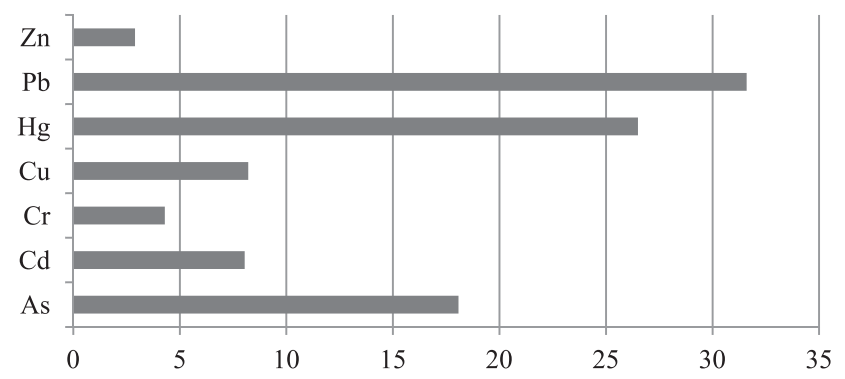

c)

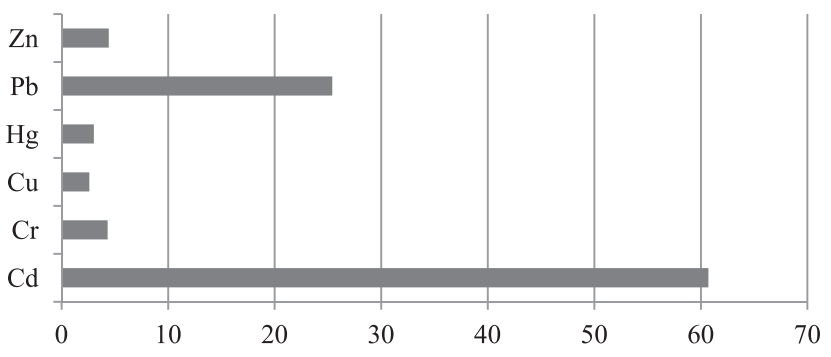

b)

$\mathbf{E}_{i} \%$

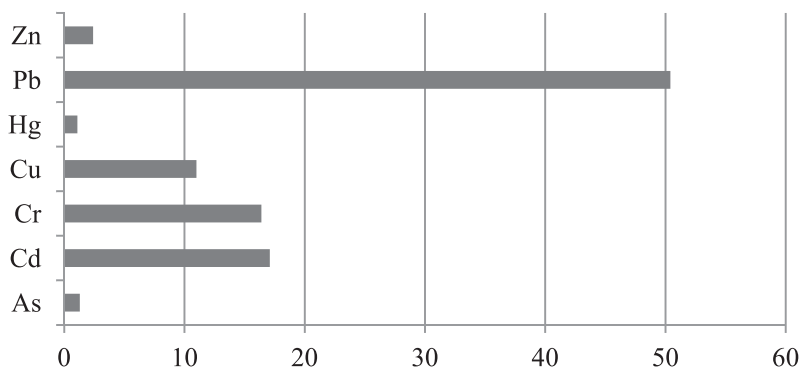

d)

$\mathbf{E}_{i} \%$

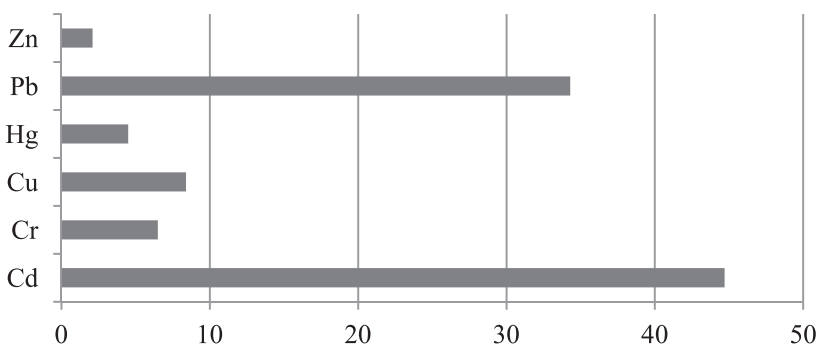

Fig. 3. Percentage of heavy metals in potential ecological risk (RI) for the soils and sediments: (a) oil fields area, (b) along highway, (c) Boyuk-Shore Lake, and (d) Bulbula Lake. 
Table 4. Classification of heavy metal pollution levels in soils and sediments based on $\mathrm{I}_{\text {geo, }}$ EF, and Ei values.

\begin{tabular}{|c|c|c|c|c|c|c|}
\hline \multirow{2}{*}{$\begin{array}{c}\text { Class } \\
1\end{array}$} & \multicolumn{2}{|r|}{$\mathrm{I}_{\mathrm{geo}}$} & \multicolumn{2}{|r|}{$\mathrm{EF}$} & \multicolumn{2}{|r|}{$\mathrm{E} i$} \\
\hline & $<0$ & $\begin{array}{c}\text { Unpolluted/ } \\
\text { slightly polluted }\end{array}$ & $<2$ & $\begin{array}{l}\text { depletion to } \\
\text { mineral enrichment }\end{array}$ & $<40$ & low potential ecological risk \\
\hline 2 & $0-1$ & moderately polluted & $2-5$ & moderate enrichment & $40-80$ & $\begin{array}{l}\text { moderate potential ecological } \\
\text { risk }\end{array}$ \\
\hline 3 & $1-3$ & $\begin{array}{l}\text { from moderately to strongly } \\
\text { polluted }\end{array}$ & $5-20$ & significant enrichment & $80-160$ & $\begin{array}{l}\text { considerable potential } \\
\text { ecological risk }\end{array}$ \\
\hline 4 & $3-5$ & strongly polluted & $20-40$ & very high enrichment & $160-320$ & high potential ecological risk \\
\hline 5 & $>5$ & extremely polluted & $>40$ & $\begin{array}{l}\text { extremely high } \\
\text { enrichment }\end{array}$ & 320 & $\begin{array}{c}\text { very high potential ecologica } \\
\text { risk }\end{array}$ \\
\hline
\end{tabular}

Fig. 3 presents the percentage of individual heavy metals in potential ecological risk index (RI) for the soils and sediments of the study area. The soils from the oil fields area had highest $\mathrm{E}_{i}$ percent for $\mathrm{Pb}, \mathrm{Hg}$, and As compared to other heavy metals. Increasingly high $\mathrm{E}_{i}$ percentages were recorded for $\mathrm{Pb}, \mathrm{Cd}$, and $\mathrm{Cr}$ in the soils from the area of transport road. It is a known fact that combustion of petroleum products by transport facilities is a major source of environmental pollution by these metals.

The contents and calculated results of pollution indices of heavy metals in the sediments of Boyuk-shore and Bulbula lakes are presented in Table 3. The measured concentrations of As in the sediments of both lakes were insignificant or below the detectable level of the analyser during our studies. Therefore, pollution indices were calculated for six metals: $\mathrm{Cd}, \mathrm{Cr}, \mathrm{Cu}, \mathrm{Hg}, \mathrm{Pb}$, and $\mathrm{Zn}$. As can be seen from the table, the mean $\mathrm{PI}_{i}$ values of $\mathrm{Cd}$, $\mathrm{Cr}, \mathrm{Cu}$, and $\mathrm{Zn}$ in the sediments of Boyuk-shore lake showed the mean concentrations several times higher than the MPC of the elements. Among toxic metals, $\mathrm{Cd}, \mathrm{Pb}$, and $\mathrm{Zn}$ each had the maximum concentrations of 5, 47.2, and $510 \mathrm{mg} / \mathrm{kg}$, respectively. The results of analysis show that the contents of the majority of the studied metals in the sediments of Bulbula Lake were lower than those in Boyuk-Shore lake, with the exception of $\mathrm{Cu}$, which had

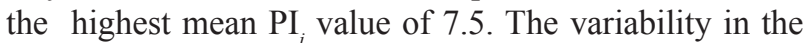
concentrations of heavy metals may be associated with the origins of their pollution sources.

The results of calculations suggest that in both lakes the mean values of $\mathrm{I}_{\text {geo }}$ and $\mathrm{EF}$ for the studied metals represent unpolluted conditions, while there are some elevated levels of $\mathrm{Cd}, \mathrm{Pb}$, and $\mathrm{Zn}$, especially in the sediments of Boyuk-Shore lake. Fig. 2 shows that the maximum EF value in the sediments of Boyuk-Shore observed in $\mathrm{Zn}$ is greater than 3, indicating that the lake was severely impacted by anthropogenic sources of this metal.

It can be seen from Fig. 2 that the values of EF for all metals in the sediment samples of Bulbula lake are less than 1, which falls within class - depletion to mineral enrichment. The mean values of $\mathrm{I}_{\text {geo. }}$ for all metals in the sediments of Bulbula lake are negative, suggesting that the lake could be categorized as "unpolluted/slightly polluted."

The E $i$ values presented in Fig. 3 indicate that the highest $\mathrm{E}_{i}$ values recorded in the sediments of BoyukShore were 17.0 for $\mathrm{Cd}$ and 7.12 for $\mathrm{Pb}$, and the highest $\mathrm{E}_{i}$ values recorded in the sediments of Bulbula lake were 6.0 for $\mathrm{Cd}$ and 4.6 for $\mathrm{Pb}$. Based on the $\mathrm{E}_{i}$ values given in Table 4 , these values are within the $1^{\text {st }}$ class characterized by low potential ecological risk. Comparable analysis of the values of EF, $\mathrm{I}_{\text {geo }}$, and $\mathrm{E}_{i}$ in the sediments of BoyukShore and Bulbula lakes shows that in both lakes the highest and lowest values of these indices were observed almost in the same elements that can be explained by their lithogenic sources. The elevated levels of heavy metals in the samples taken from Boyuk-Shore confirm that anthropogenic factors significantly contribute to the accumulation of these metals in the lake sediments.

\section{Conclusions}

Based on the results of the studies, it can be concluded that the long-term impact of anthropogenic sources has led to the pollution of the ecosystem by heavy metals in the Absheron region. The metal pollution status of soils and sediments was evaluated using different pollution indexes such as $\mathrm{PI}_{i}, \mathrm{EF}, \mathrm{I}_{\mathrm{geo}}$, and RI $\left(\mathrm{E}_{i}\right)$. The calculated values of pollution index $\left(\mathrm{PI}_{i}\right)$ indicated high levels of heavy metals, especially $\mathrm{Pb}, \mathrm{Cr}, \mathrm{Zn}$, and $\mathrm{Cu}$ in soils exceeding their MAC by several times, which is cause for serious concern. The results showed that the accumulation of metals in the soils of the study area is influenced mainly by industrial and vehicular sources, for which the latter is primarily responsible. The calculated values of EF and $\mathrm{I}_{\text {geo. }}$ were comparable for Boyuk-Shore and Bulbula lakes, and revealed that heavy metal accumulation in the sediments of both lakes was limited, representing the state of depletion to mineral enrichment. The potential ecological risk indices indicated low potential risk $(<40)$ from the heavy metals, with the exception of $\mathrm{Pb}$ posing considerable potential risk level in the area of the highway. Overall, the study area cannot be characterized by potential risk from heavy metals, but increasing industrial development and urban growth can lead to higher potential risk in future years. This study has an environmental interest and would be useful during implementation of pollution prevention measures. 


\section{References}

1. MAMEDOV V. A., ALIYEV G. I. Microelements in the waters of the Absheron peninsula and their role in environmental pollution. Transactions of Azerbaijan National Academy of Sciences: the Earth Sci. series. 2, 119, 2005 [In Russian].

2. URUSHADZE T.F., GHAMBASHIDZE G.O., BLUM W.H., MENTLER A. Soil contamination with heavy metals in Imereti Region (Georgia). Bulletin of the Georgian National Academy of Sciences. 175, 122, 2007.

3. R. MIRANDA-AVILES, M. J. PUY-ALQUIZA, O.P. ARVIZU. Anthropogenic metal content and natural background of overbank sediments from the Mining District of Guanajuato, Mexico. Soil Sediment contam. 21 (5), 604, 2012.

4. RAMESH A., NAGENDRA PRAKASH B.N., SIVAPULLAIAIH P.V. Identification of source of heavy metal contamination in a site-a case study. J Environ. Pollut. $51(1 / 2), 91,2013$.

5. GIUSTI L. Heavy metals in urban soils of Bristol (UK). Initial screening for contaminated land. J. Soils Sediments. 11, 1385, 2011.

6. DEVOLDER P. S., BROWN S. L., HESTERBERG D., PANDYA K. Metal bioavailability and speciation in a wetland tailings repository amended with biosolids compost, wood ash, and sulfate. J Environ. Qual. 32 (3) 851, 2003.

7. OSUNKIYESI A.A., TAIWO A.G, OLAWUNMI O.A., AKINDELE O.I, SOBO A.A. Environmental impact of heavy metal contaminants and micronutrients in soil samples of metal dumpsites in Abeokuta, Ogun State, Nigeria. IOSR Journal of Appl. Chem. 7 (5), 52, 2014.

8. TEPLAYA G. A. Heavy metals as a factor of environmental pollution: a review. Astrakhan proceedings of ecological education. 23 (1), 182, 2013 [In Russian].

9. SAMEDOV P.A., BABABEKOVA L. A., ALIYEVA B.B., MAMEDZADE V. T. Biological characteristics of technogenic contaminated soils. Baku: Elm publishing, 104, 2011. [in Russian].

10. ADESINA G., ADELASOYE K. Effect of crude oil pollution on heavy metal contents, microbial population in soil, and maize and cowpea growth. J Agr. Sci. 5 (1), 43, 2014.

11. OZTURK M., OZOZEN G., MINARECI O., MINARECI E. Determination of heavy metals in fish, water and sediment of Avsar Dam Lake in Turkey. Iran j. Environ. Health sci. Eng. 6, 73, 2009.

12. ALIYEV F.G., KHALILOVA H. Kh. The anthropogenic impact on surface water resources in Azerbaijan. J. Energy and Environ., 25 (2), 343, 2014.

13. KHALILOVA H. Kh. The impact of oil contamination on soil ecosystem. J. Biological and Chemical Research, 2 (3), 133, 2015.
14. ALIYEV M.I. Ecological monitoring of the Caspian Sea water area. Baku: Tahsil publishing, 290, 2009 [In Azerbaijani].

15. MAMEDOV R. M. Caspian Sea: Hydrometeorological variability and ecogeographical problems. Baku: Elm publishing, 436, 2007 [In Russian].

16. MEKHTIYEV A. SH., GUL A.K., FARAJEVA L. N. Geoecology of Baku archipelago of the Caspian Sea. Baku: NAA Publishing, 130, 2013 [In Russian].

17. HU Y., LIU X., BAI J., SHIH K., ZENG E., CHENG H. Assessing heavy metal pollution in the surface soils of a region that had undergone three decades of intense industrialization and urbanization. Environ. Sci. Pollut. Res. 20, 6150, 2013.

18. AHIAMADJIE H., ADUKPO O.K., TANDOH J.B., GYAMPO O., NYARKA M., MUMUNI L.I., AGYEMANG O., ACKAH M., OTOO F., DAMPARE S.B. Determination of the elemental contents in soils around Diamond cement factory, Aflao. Research journal of Environmental and Earth Sciences, 3 (1), 46, 2011.

19. GONG Q., DENG J., XIANG Y., WANG Q., YANG L. Calculating pollution indices by heavy metals in ecological geochemistry assessment and a case study in parks of Beijing. Journal of China University of Geosciences. 19 (3), 230, 2008.

20. LIU J., ZHUO Z., SUN SH., NING X., ZHAO S., XIE W., WANG Y., ZHENG L, HUANG R, LI B. Concentrations of heavy metals in six municipal sludges in Guangzhou and their potential ecological risk assessment for agricultural land use. Pol. J. Environ. Stud. 24 (1), 165, 2015.

21. Environmental situation and nature protecting activities in 2005-2011years. Report of the Ministry of Ecology and Natural Sources of the Republic of Azerbaijan, 2011 [In Azerbaijani].

22. MAMMADOV V. A. Lakes of Absheron Peninsula. National Atlas of the Republic of Azerbaijan. Baku Cartography Factory, 187, 2014.

23. EPA method 3052: microwave assisted acid digestion of siliceous and organically based matrices. In: Test methods for evaluating solid waste. USEPA, Washington, DC, 1996.

24. MULLER G. Index of geoaccumulation in sediments of Rhine River. Geojournal, 2, 108, 1969.

25. ISAYEV S. A., BABAYEV F.M., RAGIMZADE A. I., SULTANOV R.R. Ecologic-geochemical assessment of changes in biosphere of the Absheron peninsula. Baku: MBM Publishing, 470, 2007 [In Russian].

26. HAKANSON L. An ecological risk index for aquatic pollution control.

27. A sedimentological approach. Water. Res. 14 (8), 975, 1980.

28. MULLER G. Schwermetallein den sediments des RheinsVeraderungen Seitt 1971. Umschan. 79, 778, 1979.

29. SUTHERLAND R.A. Bed sediment - associated trace metals in an urban stream, Oahu, Hawaii. Environ. Geol. 39 (6), 611, 2000. 